\title{
Mixed-metal pillared layer clays and their pillaring precursors
}

\author{
István Pálinkó, ${ }^{a}$ Árpád Molnár, ${ }^{a}$ János B. Nagy, ${ }^{b}$ Jean-Cristoph Bertrand, ${ }^{b}$ Károly Lázár, ${ }^{c}$ \\ József Valyon ${ }^{d}$ and Imre Kiricsi ${ }^{e * \dagger}$ \\ ${ }^{a}$ Department of Organic Chemistry, József Attila University, Dóm tér 8, Szeged, H-6720 Hungary \\ ${ }^{b}$ Laboratoire de R.M.N., Facultés de Universitaires Notre-Dame de la Paix, 61 rue de Bruxelles, \\ B-5000 Namur, Belgium \\ ${ }^{c}$ Department of Catalysis and Tracer Studies, Institute of Isotopes of the Hungarian Academy of \\ Sciences, P.O. Box 77, Budapest, H-1525 Hungary \\ ${ }^{d}$ Central Research Institute for Chemistry of the Hungarian Academy of Sciences, Pusztaszeri út \\ 59-67, Budapest, H-1025 Hungary \\ e Applied Chemistry Department, József Attila University, Rerrich B. tér 1, H-6720 Hungary
}

\begin{abstract}
Mixed-metal pillared layer clays (Fe,Al-PILCs and Cr,Al-PILCs) of various compositions and the pillaring precursors have been prepared and characterised with a combination of chemical and instrumental methods. Chemical analysis data, IR, ${ }^{57}$ Mössbauer and ${ }^{27} \mathrm{Al}$ NMR spectroscopic measurements on the precipitated pillaring precursors and comparison of redox behaviour [temperature-programmed reduction (TPR) results and ${ }^{57} \mathrm{Fe}$ Mössbauer measurements on the heat-treated and the reduced samples] of the ion-exchanged and Al-pillared and mixed-metal pillared clays revealed that isomorphous substitution of $\mathrm{Al}$ for Fe or $\mathrm{Cr}$ did not occur in either the tetrahedral or the octahedral positions. Heat treatment, however, resulted in mixed-metal pillared clays which were active in both acid-catalysed and redox transformations.
\end{abstract}

Zeolites and related porous materials have gained tremendous importance in various fields of chemical industry and in both fundamental and development-oriented research. A significant class of such porous materials is the pillared layer clays (PILCs). The framework of these substances is a swellable layered silicate in which the layers are propped open by bulky polyhydroxy cations. These cations occupy some of the ionexchange positions of the clay. After not too severe heat treatment, following the removal of physisorbed water, only the pillars are dehydroxylated (they become bulky oxides) leaving behind a structure with a relatively uniform, quasi-two-dimensional channel system with pore openings of molecular size. These materials are mostly acidic and the system might appear to be suitable for cracking heavy oil residues except for the limited thermal and hydrothermal stability of the pillared structure. The system remained, however, a promising catalyst for the fine chemical industry, in reactions where shape selectivity is needed and the reaction conditions are mild.

In preparing these materials the most frequently used clays belong to the smectite family and the pillaring cations are mostly obtained by the forced partial hydrolysis of $\mathrm{AlCl}_{3}$ solution. As a result of hydrolysis the $\left[\mathrm{AlO}_{4} \mathrm{Al}_{12}(\mathrm{OH})_{24}\left(\mathrm{H}_{2} \mathrm{O}\right)_{12}\right]^{7+}$ ion, the so-called Keggin ion $^{1}$ (in the form of the sulfate or selenate salt its structure was resolved long $\mathrm{ago}^{2}$ ) is formed, together with polymeric Al cations (their ratio depending largely on the experimental conditions ${ }^{3}$ ). These polyhydroxy ions are exchanged into the preswollen clay. Obviously, polyhydroxy cations of other elements can and have been prepared and pillared layer clays containing mixed-metal pillars have also been synthesized. This topic has been recently reviewed. ${ }^{4}$

Various reactions may take place in the channel system of these materials, depending on the chemical properties of the pillars. The most common active sites are Lewis and/or Brønsted acid centres due to the intrinsic properties of the clay applied (most often Na-montmorillonite) and the most frequently used pillaring agents, the various types of poly-

† E-mail: kiricsi@chem.u-szeged.hu hydroxy Al ions. Other functions, such as redox properties, can also be introduced, either by applying another pillaring agent (co-pillaring resulting in a mixed pillared substance) or isomorphous substitution of $\mathrm{Al}$ in the Keggin ion in the tetrahedral and/or the octahedral positions. Both types of modification require ions capable of altering oxidation states and the two methods would give materials with distinctly different properties. Although ions of virtually every element have been claimed to be introduced in both the tetrahedral and the octahedral positions of the $\mathrm{Al}_{13}$-Keggin ion, ${ }^{5}$ the highly cited patent did not give any clear-cut evidence for this success. Direct proofs are accumulating slowly and only for ions of certain elements $\left(\mathrm{Ga},{ }^{6-11} \mathrm{Ge}^{12}\right)$ has isomorphous substitution been proven. From time to time papers appear in the literature reporting the success of changing aluminium for iron or chromium in the tetrahedral as well as the octahedral positions in the $\mathrm{Al}_{13}$-Keggin ion. ${ }^{13-19}$ Proofs, however, are vague, because the pillared materials were investigated instead of the salts containing the polyhydroxy cations used for pillaring.

Fortunately, a combination of thermal and instrumental methods applied to characterisation of the pillaring precursors is able to resolve the ambiguity. A, hopefully, convincing answer is given here when iron or chromium salts are used for modification. Further, we intend to show that, when the method is appropriately chosen, a comparison even between the modified and unmodified Al-PILCs and the ionexchanged substances can give a satisfactory answer. Finally, we also give some examples of catalytic applications of the pillared and the ion-exchanged clays in both acid-catalysed and redox transformations.

\section{Experimental}

\section{Materials and their preparation}

The polyoxometalate ion solutions were prepared from mixtures of $\mathrm{AlCl}_{3}$ and $\mathrm{FeCl}_{2}$ solutions where the $\mathrm{Fe} / \mathrm{Al}$ ratios were $0 / 13,0.5 / 12.5,1 / 12,2 / 11,4 / 9$ and $13 / 0$ or from mixtures of $\mathrm{AlCl}_{3}$ and $\mathrm{CrCl}_{3}$ solutions where the $\mathrm{Cr} / \mathrm{Al}$ ratios were $0 / 13,1 / 12,2 / 11,3 / 10,4 / 9$ and 13/0. These solutions were 
hydrolysed until $\mathrm{OH} /$ metal $=2$, using $\mathrm{NaOH}$ solution $(1 \mathrm{~mol}$ $\mathrm{dm}^{-3}$ ) or crystalline $\mathrm{Na}_{2} \mathrm{CO}_{3}$. The concentration of each solution was $0.25 \mathrm{~mol} \mathrm{dm}^{-3}$. Mixing was performed at room temperature and the solutions were aged overnight at $330 \mathrm{~K}$ then divided into two parts. An aliquot was used for preparation of Keggin ion sulfates and the remainder for pillaring Na-montmorillonite (Na-Mont). The Keggin ion salts were prepared by adding excess $\mathrm{Na}_{2} \mathrm{SO}_{4}$ to the solution at $\mathrm{pH} 4.5$. After 1 week the crystals were separated, flushed with slightly acidic solution, dried and stored.

Pillared montmorillonite samples were prepared using $10 \mathrm{~g}$ of $\mathrm{Na}-$ Mont and $300 \mathrm{~cm}^{3}$ of polyoxometalate solution. A $5 \%$ suspension of Na-Mont was produced using double-distilled water (preswelling the clay at room temperature with overnight stirring) and the polyoxometalate solution was added dropwise at room temperature under vigorous stirring. Stirring was maintained for $8 \mathrm{~h}$ at $353 \mathrm{~K}$.

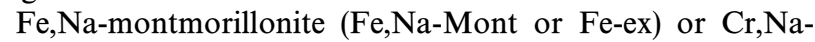
montmorillonite (Cr,Na-Mont or $\mathrm{Cr}$-ex) samples were prepared from the same Na-montmorillonite (Na-Mont) (Bentolite H, SCP Laport, BET area $=90 \mathrm{~m}^{2} \mathrm{~g}^{-1}$, $d(001)=1.46 \mathrm{~nm}, \mathrm{Fe}_{2} \mathrm{O}_{3}$ content $\left.=0.7 \mathrm{wt} . \%\right)$ by ion exchange in iron or chromium chloride solutions containing the same amount of iron as in the synthesis of Keggin-type ions applied in the pillaring process. Ion exchange was performed at $353 \mathrm{~K}$ for $8 \mathrm{~h}$, followed by washing the sample free of chloride. Finally, the solid material was separated by centrifugation and dried at room temperature.

\section{Instrumental methods of characterisation}

The iron or chromium content of the produced samples was determined by X-ray fluorescence spectroscopy. The amounts of $\mathrm{Al}^{3+}$ in the polyoxometalate salts were determined by titrimetry. The sulfate salts were dissolved in double-distilled water and the $\mathrm{Al}^{3+}$ ions were complexed with EDTA. The complexing reagent was added in excess. The excess quantity of EDTA was measured with $\mathrm{Zn}^{2+}$ ion-containing solvent. Solid $\mathrm{NH}_{4} \mathrm{~F}$ was then used to liberate EDTA from the complex, followed by titration with a $\mathrm{Zn}^{2+}$ ion-containing solution. The method is specific to $\mathrm{Al}^{3+}$ and can be used in the presence of $\mathrm{Fe}^{2+}$ or $\mathrm{Fe}^{3+}$ ions. The amounts of $\mathrm{Fe}^{3+}$ in the polyoxometalate salts were determined by a photometric method. After dissolving the sulfate salts in double-distilled water, the $\mathrm{Fe}^{3+}$ ions were complexed with KSCN. The quantity of the complex cation $\left(\left[\mathrm{Fe}(\mathrm{SCN})_{2}\right]^{+}\right.$) was determined by VIS spectrophotometry $(\lambda=460 \mathrm{~nm})$.

X-Ray diffractograms were recorded on well powdered samples with a DRON 3 diffractometer. The interlayer spacings were calculated from the 001 reflections for both the ionexchanged and the pillared samples.

BET measurements were carried out in a conventional volumetric adsorption apparatus at liquid- $\mathrm{N}_{2}$ temperature $(78 \mathrm{~K})$. Prior to measurements the samples were pretreated in vacuum at $573 \mathrm{~K}$ for $1 \mathrm{~h}$.

The thermal behaviour of the substances was studied by thermogravimetry (TG) with a Derivatograph-Q instrument. The powdered samples were placed on a platinum sample holder and the measurements were carried out under the following conditions: mass of sample $100 \mathrm{mg}$, heating rate $10 \mathrm{~K}$ $\min ^{-1}$, temperature range $300-1270 \mathrm{~K}$.

For TPR measurements, a $10 \% \mathrm{H}_{2}-\mathrm{N}_{2}$ mixture was passed through a quartz reactor containing $100 \mathrm{mg}$ of the sample. The reactor temperature was ramped at a rate of $10 \mathrm{~K} \mathrm{~min}^{-1}$. The water formed was trapped at $77 \mathrm{~K}$ downstream. A thermal conductivity detector was used to follow and record $\mathrm{H}_{2}$ consumption.

IR spectroscopic measurements were performed in the midand far-IR regions. For mid-IR measurements a Matson Genesis or a BIO-RAD FTS-65A/896 FT-IR spectrometer and the $\mathrm{KBr}$ technique ( $2 \mathrm{mg}$ of sample in $200 \mathrm{mg} \mathrm{KBr}$ ) were used. Far-IR measurements were made on a Bio-Rad-Win-IR FTIR spectrometer in the $500-100 \mathrm{~cm}^{-1}$ range using a $2 \mathrm{mg}$ sample in $200 \mathrm{mg}$ high-density polyethylene and 128 scans were collected for one spectrum. Spectra were corrected for the water spectrum.

${ }^{57} \mathrm{Fe}$ Mössbauer spectra were recorded in an in situ cell at $77 \mathrm{~K}$. A ${ }^{57} \mathrm{Co} / \mathrm{Cr}$ source was used in constant acceleration mode. The isomer shifts are relative to metallic $\alpha-F e$. The spectra of the 'as-prepared', as well as the heat-treated or reduced (from 373 to $673 \mathrm{~K}$ by $100 \mathrm{~K}$ increments under a slow $\mathrm{N}_{2}$ flow, followed by reduction under a slow $\mathrm{H}_{2}$ flow at the same temperature) samples were recorded. Spectra were computer-fitted and isomer shifts, quadrupole splittings, relative intensities etc. were deduced.

Solution ${ }^{27} \mathrm{Al}$ NMR measurements were applied (i) to check the formation of the Keggin unit after the forced partial hydrolysis of $\mathrm{AlCl}_{3}$ and that of the metal salt mixtures and (ii) to the supernatant after precipitating the polyoxometalate ions with $\mathrm{Na}_{2} \mathrm{SO}_{4}$ solution. The solution ${ }^{27} \mathrm{Al} \mathrm{NMR} \mathrm{spectra}$ were recorded on a Bruker MSL400 spectrometer at 104.2 $\mathrm{MHz}$. Chemical shifts were referenced to $\mathrm{Al}\left(\mathrm{NO}_{3}\right)_{3}$ solution. The sulfate precipitates of the hydrolysed $\mathrm{AlCl}_{3}$, cohydrolysed $\mathrm{AlCl}_{3}-\mathrm{FeCl}_{2}$ or $\mathrm{AlCl}_{3}-\mathrm{CrCl}_{3}$ mixtures and the pillared clays were studied with ${ }^{27} \mathrm{Al}$ magic-angle spinning (MAS) NMR spectroscopy. Spectra were recorded on a Bruker MSL400 spectrometer at 104.2 MHz. The spinning rate was $3.8 \mathrm{kHz}$; the pulse lengths corresponded to $\pi / 12(1.0$ $\mu \mathrm{s})$. In the initial measurements, variable waiting time was applied and $10 \mathrm{~s}$ was found to be the most appropriate. To calculate the ratio of octahedral to tetrahedral aluminium, the integrated areas of the relevant resonances were used.

\section{Characterisation by chemical methods}

The acidity of the samples was characterized by the IR spectra of adsorbed pyridine. Self-supported wafers were pressed and degassed in situ in the optical cell at $573 \mathrm{~K}$, which was then cooled to $473 \mathrm{~K}$ before loading with pyridine. The wafer was kept in pyridine vapour for $1 \mathrm{~h}$ followed by evacuation at the same temperature. Bands at 1450 and $1540 \mathrm{~cm}^{-1}$ were considered as diagnostic for Lewis and Brønsted acidity, respectively.

Acidity was also tested by various reactions such as the ring opening of cyclopropane and the subsequent oligomerisation of the propylene product (closed static circulation reactor, 100 $\mathrm{mg}$ clay samples, $13.3 \mathrm{kPa}$ cyclopropane, $573 \mathrm{~K}$ ), isomerization of but-1-ene (closed circulation reactor, $100 \mathrm{mg}$ clay sample, $13.3 \mathrm{kPa}$ of but-1-ene, $373 \mathrm{~K}$ ) and methyloxirane (pulse technique, $50 \mathrm{mg}$ clay sample, $423 \mathrm{~K}$ ), dehydration of propan-2-ol (pulse technique, $50 \mathrm{mg}$ of clay samples, $473 \mathrm{~K}$ ) and the pinacol rearrangement of 2,3-dimethylbutane-2,3-diol (sealed tube, $398 \mathrm{~K}, 1 \mathrm{~h}$ reaction time, catalyst/diol $=5 / 1$ ).

The redox properties of the Cr-containing materials were tested in the oxidation of 1-phenylpropan-1-ol in a well stirred batch reactor under $\mathrm{N}_{2}$ atmosphere, at $298 \mathrm{~K}$ using tert-butylhydroperoxide in $\mathrm{CH}_{2} \mathrm{Cl}_{2}$ over various amounts of catalysts.

The method of analysis was gas chromatography (Carlo Erba Fractovap 2150, Hewlett-Packard Models 5710 or 5890 gas chromatographs equipped with flame ionization detectors) using various packed all-glass columns such as bis(2-methoxyethyl)adipate/ Chromosorb PAW or 1:1 ODPN-Reoplex 400/ Chromosorb W.

\section{Results \\ Characterisation by conventional methods}

XRD and BET measurements. XRD and BET measurements on the heat-treated samples revealed that ionexchanged polyhydroxy ions propped the layers of the clay open and the pillared structure remained stable up to $773 \mathrm{~K}$. As a result of ion exchange, as well as pillaring, the basal 
spacing increased. The latter process afforded larger interlayer distances, since the $\mathrm{Al}_{13}$-Keggin ion is larger than the simple $\mathrm{Fe}^{3+}$ or $\mathrm{Cr}^{3+}$ ions. BET surfaces increased by $c a$. $60 \%$ upon ion exchange while two- to three-fold increase was measured after pillaring. Characteristic data are listed in Table 1.

Thermogravimetric measurements. For the ion-exchanged samples, dehydration took place between 370 and $390 \mathrm{~K}$ and dehydroxylation occurred between 940 and $960 \mathrm{~K}$. Treatment above $960 \mathrm{~K}$ resulted in the collapse of the layered structure. For the pillared materials three weight-loss steps were observed. The second step (between 660 and $690 \mathrm{~K}$ ) with a weight loss of $2-3 \%$ appears, conceivably, to be due to the dehydroxylation of the pillars.

Temperature programmed reduction TPR. TPR patterns are displayed in Fig. 1. Hydrogen uptake, calculated as the number of electrons/number of iron species was small for Na-Mont (1.14) and also for Al-PILC (1.72). The values for the other two substances were identical (2.85). The temperature maxima were found at lower temperatures for the samples containing iron in high concentration and mostly inbetween the silicate sheets (Fe,Na-Mont, $\mathrm{Fe}_{4} \mathrm{Al}_{9}$-PILC).

Chemical analysis. Quantitative analysis of the redissolved sulfate salt obtained by the precipitation of a solution resulting from the forced hydrolysis of $\mathrm{FeCl}_{2}+\mathrm{AlCl}_{3}$ mixture with $\mathrm{Fe} / \mathrm{Al}$ ratio $1 / 25$ revealed that the $\mathrm{Fe} / \mathrm{Al}$ ratio was $6 / 1000$, almost an order of magnitude less than it should have been if isomorphous substitution had taken place.

\section{Spectroscopic characterisation}

${ }^{27}$ Al NMR spectroscopy. In solution, the intensity of the line near $0 \mathrm{ppm}$, the signal of octahedrally coordinated monomeric $\mathrm{Al}^{3+}$, decreased and a line near $63 \mathrm{ppm}$ appeared and grew. This line is the signal of tetrahedral aluminium in the $\mathrm{Al}_{13}$-Keggin ion (Fig. 2, A-D). It is appropriate to remark that NMR-silent polymeric aluminium ions may have also been formed, ${ }^{3,20}$ making the ${ }^{27} \mathrm{Al}$ NMR measurements in solution only qualitative. Nevertheless, measurements show that forced hydrolysis of the salt mixtures clearly results in the

Table 1 Characteristic data on the ion-exchanged and pillared materials

\begin{tabular}{lcc}
\hline & $d(001)^{a} / \mathrm{nm}$ & $\mathrm{BET}^{b} / \mathrm{m}^{2} \mathrm{~g}^{-1}$ \\
\hline Ion-exchanged materials & & \\
Na-Mont & 1.46 & 90.0 \\
$\mathrm{Fe}_{1}$ Na-Mont & 1.52 & 138.9 \\
$\mathrm{Fe}_{2}$ Na-Mont & 1.53 & 124.5 \\
$\mathrm{Fe}_{4}$ Na-Mont & 1.50 & 169.9 \\
$\mathrm{Cr}_{1}$ Na-Mont & 1.57 & 97.8 \\
$\mathrm{Cr}_{2}$ Na-Mont & 1.57 & 97.7 \\
$\mathrm{Cr}_{3}$ Na-Mont & 1.57 & 97.8 \\
$\mathrm{Cr}_{4}$ Na-Mont & 1.57 & 142.8 \\
$\mathrm{Pillared} \mathrm{materials}$ & & \\
$\mathrm{Al}$-PILC & 1.84 & 265.5 \\
$\mathrm{Fe}_{0.5} \mathrm{Al}_{12.5}$-PILC & 1.90 & 300.8 \\
$\mathrm{Fe}_{1} \mathrm{Al}_{12}$-PILC & 1.80 & 221.3 \\
$\mathrm{Fe}_{2} \mathrm{Al}_{11}$-PILC & 1.82 & 256.0 \\
$\mathrm{Fe}_{4} \mathrm{Al}_{9}$-PILC & 1.80 & 211.6 \\
$\mathrm{Fe}_{-}-\mathrm{PILC}$ & 1.47 & 162.6 \\
$\mathrm{Cr}_{1} \mathrm{Al}_{12}$-PILC & 1.90 & 225.7 \\
$\mathrm{Cr}_{2} \mathrm{Al}_{11}$-PILC & 1.91 & 224.3 \\
$\mathrm{Cr}_{3} \mathrm{Al}_{10}$-PILC & 1.90 & 174.6 \\
$\mathrm{Cr}_{4} \mathrm{Al}_{9}$-PILC & 1.90 & 171.2 \\
$\mathrm{Cr}^{-P I L C}$ & 1.88 & 152.3 \\
\hline
\end{tabular}

${ }^{a}$ Air-dried samples. ${ }^{b}$ Heat-treated samples (evacuation at $573 \mathrm{~K}$ for $1 \mathrm{~h})$.

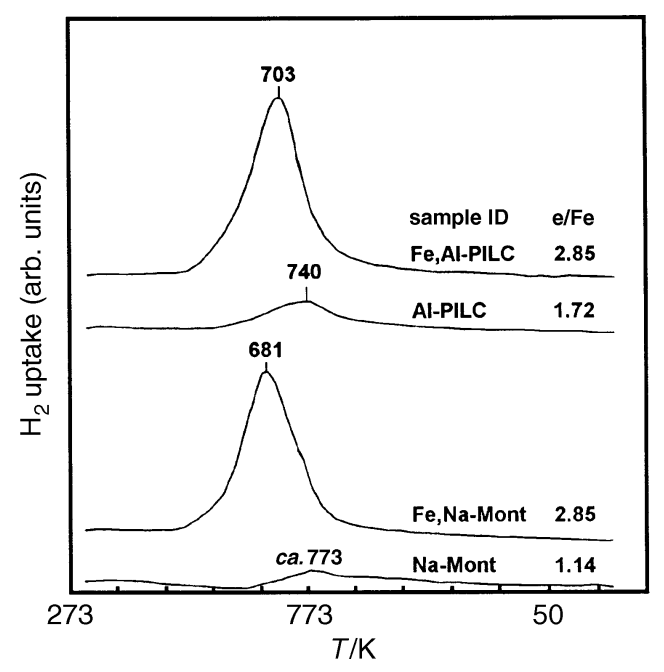

Fig. 1 TPR of the parent and the modified montmorillonite samples (the temperature was raised to $773 \mathrm{~K}$ and held at $773 \mathrm{~K}$ for $1 \mathrm{~h}$ )

formation of the $\mathrm{Al}_{13}$-Keggin unit.

After the forced partial hydrolysis, the sulfate salts were precipitated, filtered, dried and examined by NMR (Fig. 3). The ${ }^{27} \mathrm{Al}$ solution NMR spectrum of the filtrate of the $\mathrm{Al}_{13}$-Keggin

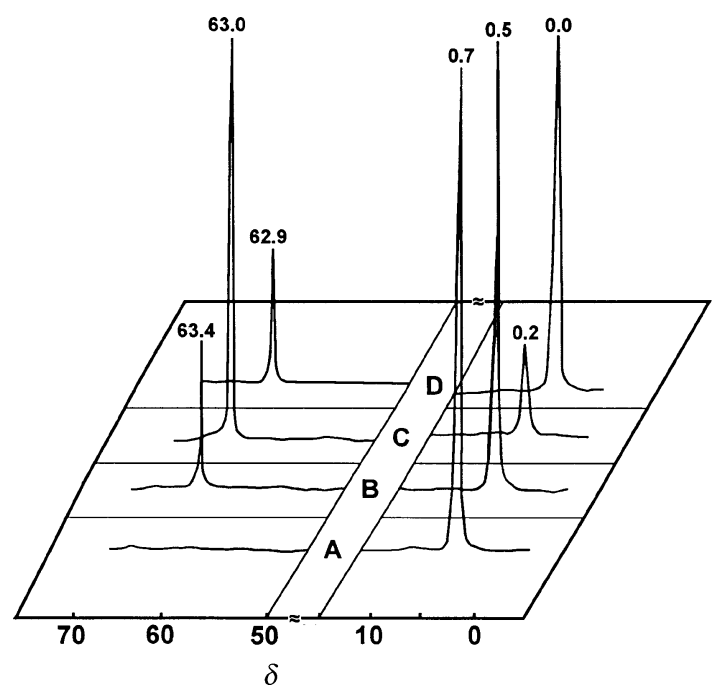

Fig. $2{ }^{27} \mathrm{Al}$ solution NMR spectra of $\mathrm{AlCl}_{3}$ and other metal salt mixtures: $\mathrm{A}, \mathrm{Fe}: \mathrm{Al}=1: 12$ non-hydrolysed; $\mathrm{B}, \mathrm{Fe}: \mathrm{Al}=1: 12$ partially hydrolysed; $\mathrm{C}, \mathrm{Fe}: \mathrm{Al}=1: 25$ partially hydrolysed; $\mathrm{D}$, $\mathrm{Cr}: \mathrm{Al}=1: 12$ partially hydrolysed

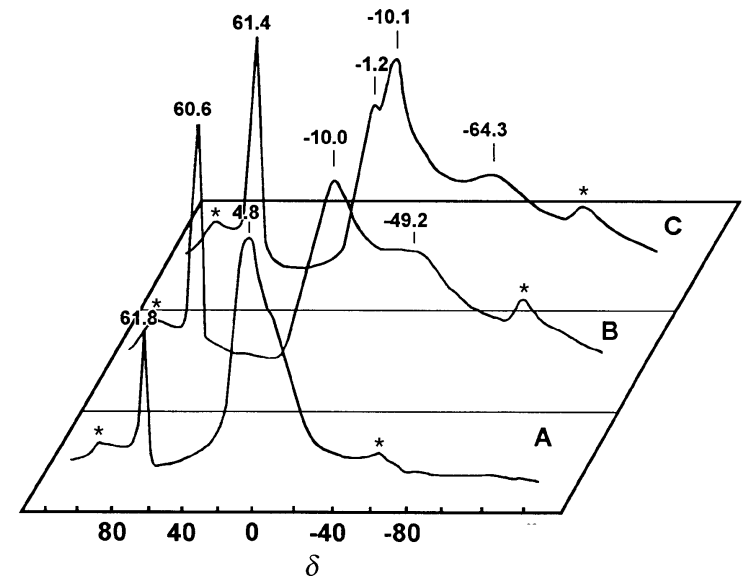

Fig. $3{ }^{27} \mathrm{Al}$ MAS NMR spectra of the mixed-metal sulfates: A $\mathrm{Fe}: \mathrm{Al}=0: 13 ; \mathrm{B}, \mathrm{Fe}: \mathrm{Al}=1: 12 ; \mathrm{C}, \mathrm{Cr}: \mathrm{Al}=1: 12$

J. Chem. Soc., Faraday Trans., 1997, Vol. 93 
sulfate revealed that the $\mathrm{Al}_{13}$-Keggin ion formed in solution was fully precipitated. The $\mathrm{Al}^{\mathrm{O}} / \mathrm{Al}^{\mathrm{T}}$ was calculated to be 11.9 , as expected (Fig. 3, A). The presence of paramagnetic ions did not decrease the quality of the spectra, except by splitting the broad octahedral resonance in the $\mathrm{Al}_{13}$-Keggin sulfate (Fig. 3, $\mathrm{B}$ and $\mathrm{C}$ ). Tetrahedral aluminium continued to give sharp lines near $60 \mathrm{ppm}$ and the $\mathrm{Al}^{\mathrm{O}} / \mathrm{Al}^{\mathrm{T}}$ ratios were 8.0 and 11.5 for the $\mathrm{Fe}, \mathrm{Al}$ and the $\mathrm{Cr}, \mathrm{Al}$ mixed ions, respectively.

${ }^{27}$ Al MAS NMR has frequently been applied to the characterisation of pillared layer clays. The results are widely reported. ${ }^{21}$ Note, however, that the method only gives accurate and quantifiable information about the pillars and the pillaring process if the clay does not contain aluminium in either the octahedral $^{22}$ or the tetrahedral sheet. ${ }^{23}$ In the most frequently used host material, Na-montmorillonite, aluminium substitutes for silicon in the tetrahedral layer, giving rise to the $\mathrm{Al}^{\mathrm{T}}$ signal, even without the presence of any kind of aluminiumcontaining intercalant (Figure 4, A). Although the $\mathrm{Al}^{\mathrm{T}}$ signal, shifted and sharpened upon introducing the $\mathrm{Al}_{13}$-Keggin ion so also did the $\mathrm{Al}^{\mathrm{O}}$ signal (Fig. 4, B), quantitative evaluation is incidental, since the integrated areas are the superposition of the relevant lines of both the host and the guest materials. Incorporation of $\mathrm{Fe}^{3+}$ or $\mathrm{Cr}^{3+}$ resulted in line broadening (Fig. 4, C and D) with no, or slight, changes in the $\mathrm{Al}^{\mathrm{O}} / \mathrm{Al}^{\mathrm{T}}$ ratio.

${ }^{57}$ Fe Mössbauer spectroscopy. Keggin ion sulfates crystallized from $\mathrm{AlCl}_{3}-\mathrm{FeCl}_{2}$ solutions of various compositions and treated with $\mathrm{Na}_{2} \mathrm{SO}_{4}$ were bright yellow in colour. The depth and intensity of the colour increased with increasing iron content. An iron-sensitive method such as ${ }^{57} \mathrm{Fe}$ Mössbauer spectroscopy can detect the coordination and oxidation

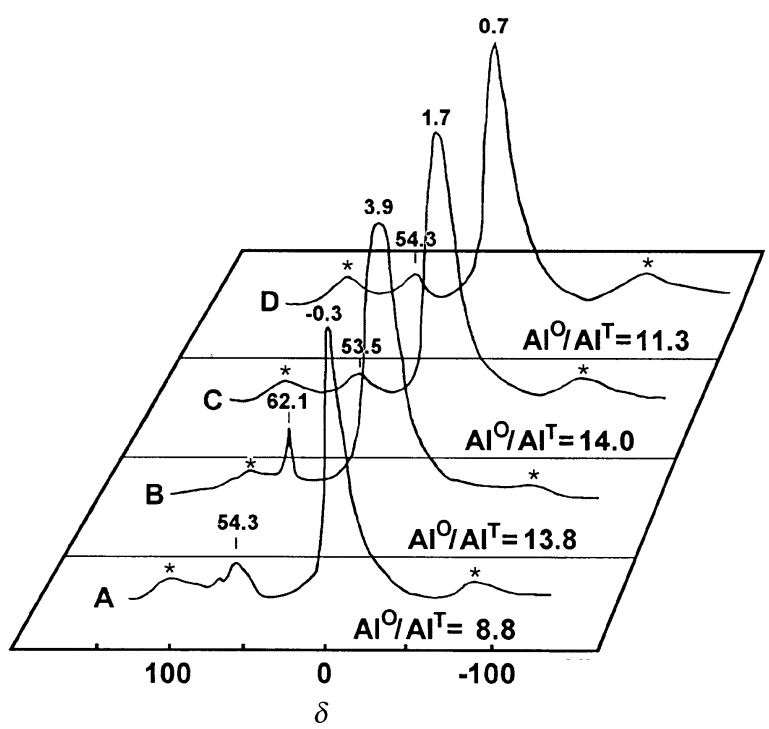

Fig. $4{ }^{27} \mathrm{Al}$ MAS NMR spectra of A, Na-montmorillonite and the pillared layer clay samples with synthetic metal/Al ratios; $\mathrm{B}, \mathrm{Fe}$ (or $\mathrm{Cr}): \mathrm{Al}=0: 13 ; \mathrm{C}, \mathrm{Fe}: \mathrm{Al}=1: 12$ and $\mathrm{D}, \mathrm{Cr}: \mathrm{Al}=1: 12$ states of iron ions covering the $\mathrm{Al}_{13}$-Keggin ion. Relevant data for the ion with the nominal $\mathrm{Fe}$ to $\mathrm{Al}$ ratio 2/11 are listed in Table 2. The spectrum originating from the as-synthesized Keggin ion sulfate, indicated the major presence of octahedrally coordinated $\mathrm{Fe}^{3+}$, together with an $\mathrm{Fe}^{2+}$ component, present also in octahedral coordination. Upon evacuation and nitrogen treatment a significant autoreduction of $\mathrm{Fe}^{3+}$ took place. The subsequent reduction in hydrogen resulted in only a limited further decrease in the $\mathrm{Fe}^{3+}$ contribution, a significant portion was not accessible to hydrogen and preserved its ferric state (Table 2).

Data obtained from the decomposition of $78 \mathrm{~K}$ spectra of the 'as-prepared' samples and those treated at 473 and $673 \mathrm{~K}$ are summarized in Table 3 for an ion-exchanged, an $\mathrm{Fe}, \mathrm{Al}-$ pillared and an Fe-pillared material. The 'as prepared' samples, the ion-exchanged and the Fe,Al-pillared substances contained iron overwhelmingly in an octahedrally coordinated +3 oxidation state with a few per cent in an octahedrally coordinated +2 oxidation state. Iron(III) in the Fe-pillared material was located in a coordination probably different from those characteristic for the ion-exchanged and the Fe,Al-pillared samples, as differences in the quadrupole splittings attest.

The $473 \mathrm{~K}$ treatment resulted in reduction, to differing extents, as reflected in the $300 \mathrm{~K}$ spectra (Fig. 5). A moderate $\mathrm{Fe}^{\text {III }}$ to $\mathrm{Fe}^{\text {II }}$ reduction was detected in the ion-exchanged sample. As the treatment temperature was raised, the environ-

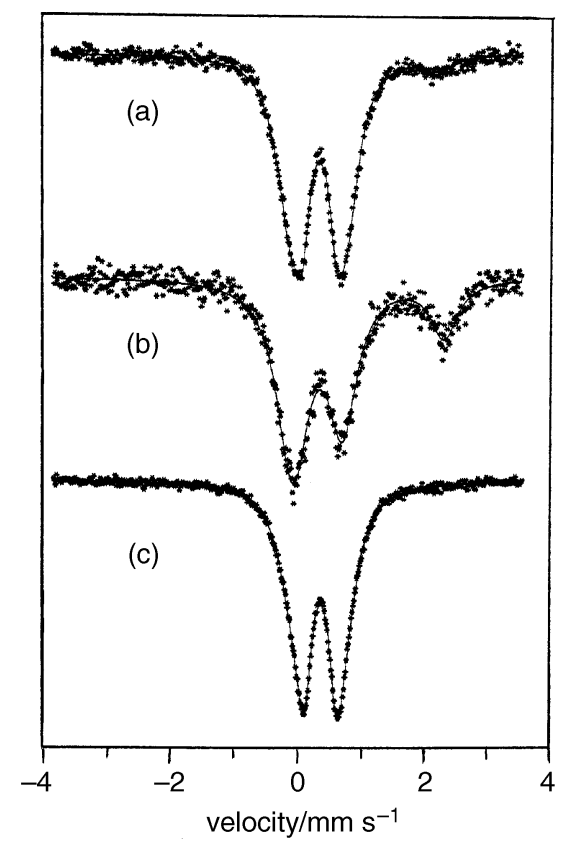

Fig. $5300 \mathrm{~K}$ Mössbauer spectra of samples treated at $473 \mathrm{~K}$ and subsequently in streams of nitrogen and hydrogen: (a) $\mathrm{Fe}_{3} \mathrm{Na}$ Montmorillonite, (b) $\mathrm{Fe}_{2} \mathrm{Al}_{11}$-PILC and (c) Fe-PILC

Table 2 Isomer shift, quadrupole splitting, linewidth and relative spectral contribution values extracted from $300 \mathrm{~K}$ Mössbauer spectra of coprecipitated $\mathrm{Al}_{13}$-Keggin sulfate and hydrous iron oxide after various treatments

\begin{tabular}{|c|c|c|c|c|c|c|c|c|c|c|c|c|}
\hline & \multicolumn{4}{|c|}{ as prepared } & \multicolumn{4}{|c|}{$\begin{array}{c}\text { evacuated at } 623 \mathrm{~K} \\
\text { in } \mathrm{N}_{2}\end{array}$} & \multicolumn{4}{|c|}{$\begin{array}{l}\text { evacuated at } 623 \mathrm{~K} \\
\text { in } \mathrm{N}_{2}-\mathrm{H}_{2}\end{array}$} \\
\hline & $\mathrm{IS}^{a}$ & $\mathrm{QS}^{b}$ & $\mathrm{FWHM}^{c}$ & $I^{d}$ & $\mathrm{IS}^{a}$ & $\mathrm{QS}^{b}$ & $\mathrm{FWHM}^{c}$ & $I^{d}$ & $\mathrm{IS}^{a}$ & $\mathrm{QS}^{b}$ & $\mathrm{FWHM}^{c}$ & $I^{d}$ \\
\hline $\mathrm{Fe}^{\mathrm{III}}$-oct & 0.34 & 0.75 & 0.55 & 84 & 0.32 & 0.92 & 0.61 & 45 & 0.31 & 0.87 & 0.61 & 35 \\
\hline $\mathrm{Fe}^{\mathrm{II}}$-oct & 1.12 & 2.31 & 0.64 & 16 & 1.09 & 2.18 & 0.74 & 55 & 1.12 & 2.19 & 0.71 & 65 \\
\hline
\end{tabular}

${ }^{a}$ Isomer shift, $\mathrm{mm} \mathrm{s}^{-1}$ relative to $\alpha$-iron. ${ }^{b}$ Quadruple splitting, $\mathrm{mm} \mathrm{s}^{-1} \cdot{ }^{c}$ Linewidth, $\mathrm{mm} \mathrm{s}^{-1} .{ }^{d}$ Relative spectral contribution (\%). 
Table 3 Isomer shift, quadrupole splitting, linewidth, relative intensity, and magnetic hyperfine field data measured at $77 \mathrm{~K}$

\begin{tabular}{|c|c|c|c|c|c|c|c|c|c|c|c|c|c|}
\hline & \multicolumn{4}{|c|}{$\mathrm{Fe}_{3} \mathrm{Na}-\mathrm{Mont}$} & \multicolumn{4}{|c|}{$\mathrm{Fe}_{2} \mathrm{Al}_{11}-\mathrm{PILC}$} & \multicolumn{5}{|c|}{ Fe-PILC } \\
\hline & IS & QS & FWHM & $I$ & IS & QS & FWHM & $I$ & IS & QS & MHF & FWHM & $I$ \\
\hline \multicolumn{14}{|c|}{ As prepared } \\
\hline $\mathrm{Fe}^{\mathrm{II} a}$ & 1.61 & 2.74 & 0.25 & 5 & 1.43 & 2.35 & 0.22 & 4 & - & - & - & - & - \\
\hline $\mathrm{Fe}^{\mathrm{III} b}$ & 0.43 & 0.72 & 0.51 & 95 & 0.43 & 0.75 & 0.52 & 96 & 0.44 & 0.86 & - & 0.48 & 45 \\
\hline $\mathrm{Fe}^{\mathrm{III} c}$ & - & - & - & - & - & - & - & - & 0.45 & 0.52 & - & 0.33 & 55 \\
\hline \multicolumn{14}{|c|}{$473 \mathrm{~K}, \mathrm{~N}_{2}$ flow $(1.5 \mathrm{~h}), \mathrm{H}_{2}$ flow $(1.5 \mathrm{~h})$} \\
\hline $\mathrm{Fe}^{\text {II } a}$ & 1.40 & 2.56 & 0.78 & 13 & 1.38 & 2.54 & 0.54 & 33 & - & - & - & - & - \\
\hline $\mathrm{Fe}^{\mathrm{III} b}$ & 0.43 & 0.81 & 0.56 & 87 & 0.37 & 0.93 & 0.57 & 67 & 0.43 & 0.96 & - & 0.64 & 21 \\
\hline $\mathrm{Fe}^{\mathrm{III} c}$ & - & - & - & - & - & - & - & - & 0.45 & 0.55 & - & 0.34 & 37 \\
\hline $\mathrm{M}(\mathrm{A}, \mathrm{B})$ & - & - & - & - & - & - & - & - & 0.45 & - & 45.6 & 2.04 & 42 \\
\hline \multicolumn{14}{|c|}{$673 \mathrm{~K}, \mathrm{~N}_{2}$ flow $(1.5 \mathrm{~h}), \mathrm{H}_{2}$ flow $(1.5 \mathrm{~h})$} \\
\hline $\mathrm{Fe}^{\mathrm{II} a}$ & 1.25 & 2.88 & 0.38 & 47 & 1.34 & 2.73 & 0.48 & 47 & 1.13 & 2.58 & - & 0.83 & 17 \\
\hline $\mathrm{Fe}^{\mathrm{II} d}$ & 1.22 & 2.40 & 0.49 & 35 & 1.08 & 2.65 & 0.44 & 36 & - & - & - & - & - \\
\hline $\mathrm{Fe}^{\mathrm{III} b}$ & 0.34 & 0.73 & 0.59 & 19 & 0.40 & 0.74 & 0.74 & 17 & - & - & - & - & - \\
\hline $\mathrm{M}(\mathrm{A})^{e}$ & - & - & - & - & - & - & - & - & 0.37 & - & 50.1 & 0.43 & 32 \\
\hline $\mathrm{M}(\mathrm{B})^{e}$ & - & - & - & - & - & - & - & - & 0.77 & 0.19 & 48.0 & 1.10 & 51 \\
\hline
\end{tabular}

IS, QS, FWHM and $I$ as in Table 2. MHF, magnetic hyperfine field, T. ${ }^{a}$ Octahedral-1 position for Fe ${ }^{\text {II }}{ }^{b}$ octahedral-1 position for Fe ${ }^{\text {III }}$ ${ }^{c}$ octahedral-2 position for $\mathrm{Fe} \mathrm{e}^{\mathrm{III}} ;{ }^{d}$ octahedral-2 position for $\mathrm{Fe}^{\mathrm{II}} ;{ }^{e} \mathrm{M}(\mathrm{A})$ and $\mathrm{M}(\mathrm{B})$ are different sites in the spinel structure of megnetite, for $\mathrm{M}(\mathrm{A}$,

B) these sites are not resolved.

ment of $\mathrm{Fe}^{\mathrm{II}}$ changed, owing to the gradual loss of water and chlorine. The change was reflected in the isomer shift data.

The extent of reduction in the Fe,Al-pillared sample was more significant $\left(33 \%\right.$ cf. $\left.13 \% \mathrm{Fe}^{\mathrm{II}}\right)$. In contrast, no apparent reduction of $\mathrm{Fe}^{\mathrm{III}}$ was detected in the Fe-pillared sample, i.e. the existence of a phase or component, containing iron solely in the $\mathrm{Fe}^{\mathrm{II}}$ state was not revealed. Instead, superparamagnetic behaviour was observed, as comparison of spectra obtained at $78 \mathrm{~K}$ (Table 3) with those obtained at $300 \mathrm{~K}$ [Fig. 5(c)] attests. Reduction probably did proceed in this sample, the presence of $\mathrm{Fe}^{\mathrm{II}, \mathrm{III}}$ mixed oxides could exhibit the detected antiferromagnetic ordering. The suggestion is in accord with results obtained on the Fe-pillared sample after treatment at $673 \mathrm{~K}$. The major component of the corresponding spectrum was magnetite, exhibiting the characteristic MHF values of the $\mathrm{A}$ and $\mathrm{B}$ sites, occupied solely by $\mathrm{Fe}^{\mathrm{III}}$, or a mixture of $\mathrm{Fe}^{\mathrm{III}}$ and $\mathrm{Fe}^{\mathrm{II}}$, respectively.

In the other two samples, treatment at $673 \mathrm{~K}$ resulted in a high extent of reduction. The isomer shift values obtained for the $\mathrm{Fe}^{\mathrm{II}}$ component in the $\mathrm{Fe}$,Al-pillared sample were different from those observed for the ion-exchanged material. This may be attributed to the formation of a mixed Al,Fe oxide phase (e.g. hercynite: $\mathrm{FeAl}_{2} \mathrm{O}_{4}$ ) in the $\mathrm{Fe}$,Al-pillared clay.

FT-IR spectroscopy. The positions of the absorption bands for the $\mathrm{Al}_{13}$-Keggin sulfate, the co-hydrolysed and cocrystallized $\mathrm{Fe}, \mathrm{Al}$ and $\mathrm{Cr}, \mathrm{Al}$ sulfates with various metal/Al ratios and the $\mathrm{GaAl}_{12}$-Keggin sulfate are listed in Table 4.
For band assignment the work of Bradley et al. was used. ${ }^{24}$ The bands of the $\mathrm{Al}_{13}$-Keggin sulfate form the basis of the comparison and those of the $\mathrm{GaAl}_{12}$-Keggin sulfate (where $\mathrm{Ga}$ for $\mathrm{Al}$ substitution in the tetrahedral position surely takes place $^{9}$ ) are also included, in order to have a reference in assessing band shifts thought to indicate isomorphous substitution. In the IR spectra of the co-hydrolysed Fe,Al ions, bands due to $(\mathrm{Al}-\mathrm{O})^{\mathrm{T}},(\mathrm{Al}-\mathrm{OH})^{\mathrm{O}},(\mathrm{Al}-\mathrm{O})^{\mathrm{O}}$, and $\left(\mathrm{Al}-\mathrm{OH}_{2}\right)^{\mathrm{O}}$ only, were found. The bands retained the positions observed in the $\mathrm{Al}_{13}$-Keggin sulfate. At low stoichiometric ratios $(\mathrm{Fe} /$ $\mathrm{Al}=1: 12$ and $2: 11$ ) no band typical of either tetrahedrally or octahedrally coordinated iron could be detected. When the proportion of iron was increased at the low-frequency end of the spectrum (near $465 \mathrm{~cm}^{-1}$ ) a new band started to develop. This can be ascribed to octahedrally coordinated iron in the coprecipitated hydrous iron oxide.

The IR characteristics of the $\mathrm{Cr}, \mathrm{Al}$ sulfates were different. Even at the lowest $\mathrm{Cr} / \mathrm{Al}$ ratio bands at 764 and $525 \mathrm{~cm}^{-1}$ started to develop. The latter was so intense (and its spectral area increased with chromium content) that it suppressed all other weaker bands. Only the band typical for $(\mathrm{Al}-\mathrm{OH})^{\mathrm{O}}$ remained unchanged. Although the $(\mathrm{Al}-\mathrm{O})^{\mathrm{T}}$ band was not detectable in any of the $\mathrm{Cr}, \mathrm{Al}$ ions, tetrahedral substitution did not seem to be probable, since the $(\mathrm{Cr}-\mathrm{O})^{\mathrm{T}}$ band was not found and it is known that $\mathrm{Cr}^{3+}$ tends to adopt octahedral coordination rather than tetrahedral. ${ }^{25}$

As expected from measurements on the ions, the corresponding spectra of the pillared and the ion-exchanged

Table 4 Location of absorption bands of co-hydrolysed Keggin-type ions with various metal/Al ratios in the $800-400 \mathrm{~cm}^{-1}$ range

\begin{tabular}{|c|c|c|c|c|}
\hline \multirow{2}{*}{$\frac{\text { metal/Al }}{\mathrm{Ga} / \mathrm{Al}}$} & \multicolumn{4}{|c|}{ location of absorption bands } \\
\hline & & & & \\
\hline $0 / 13$ & $720(\mathrm{Al}-\mathrm{O})^{\mathrm{T}}$ & $611(\mathrm{Al}-\mathrm{OH})^{\mathrm{O}}$ & $548(\mathrm{Al}-\mathrm{O})^{\mathrm{O}}$ & $494\left(\mathrm{Al}-\mathrm{OH}_{2}\right)^{\mathrm{O}}$ \\
\hline $1 / 12$ & 698 & 610 & 543 & 491 \\
\hline \multicolumn{5}{|l|}{$\mathrm{Fe} / \mathrm{Al}$} \\
\hline $1 / 12$ & 720 & 614 & 551 & 494 \\
\hline $2 / 11$ & 723 & 616 & 551 & 492 \\
\hline $3 / 10$ & 720 & 609 & 545 & 465 \\
\hline $4 / 9$ & 722 & 615 & 552 & 465 \\
\hline \multicolumn{5}{|l|}{$\mathrm{Cr} / \mathrm{Al}$} \\
\hline $1 / 12$ & 764 & 610 & 525 & - \\
\hline $2 / 11$ & 764 & 610 & 526 & - \\
\hline $3 / 10$ & 764 & 611 & 525 & - \\
\hline $4 / 9$ & 764 & 610 & 525 & - \\
\hline
\end{tabular}



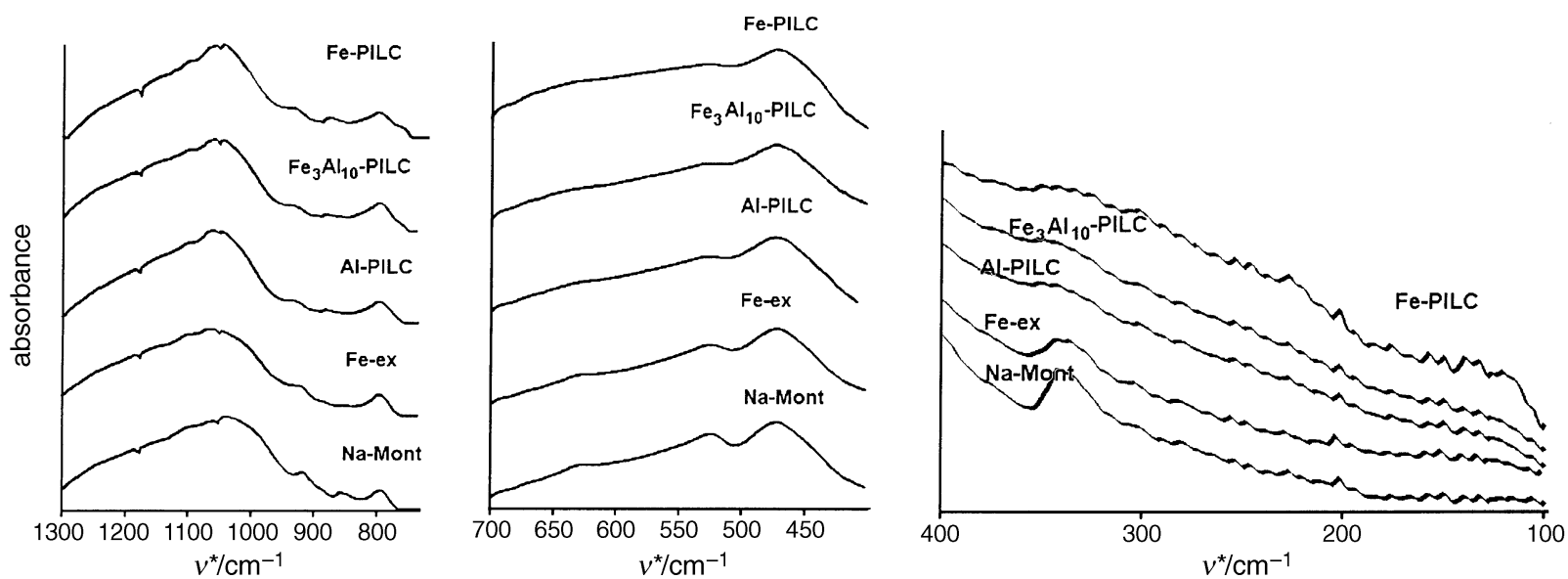

Fig. 6 IR spectra of the parent montmorillonite (Na-Mont), the Al-PILC and the iron modified clay samples in the $1300-100 \mathrm{~cm}^{-1} \mathrm{range}^{-}$
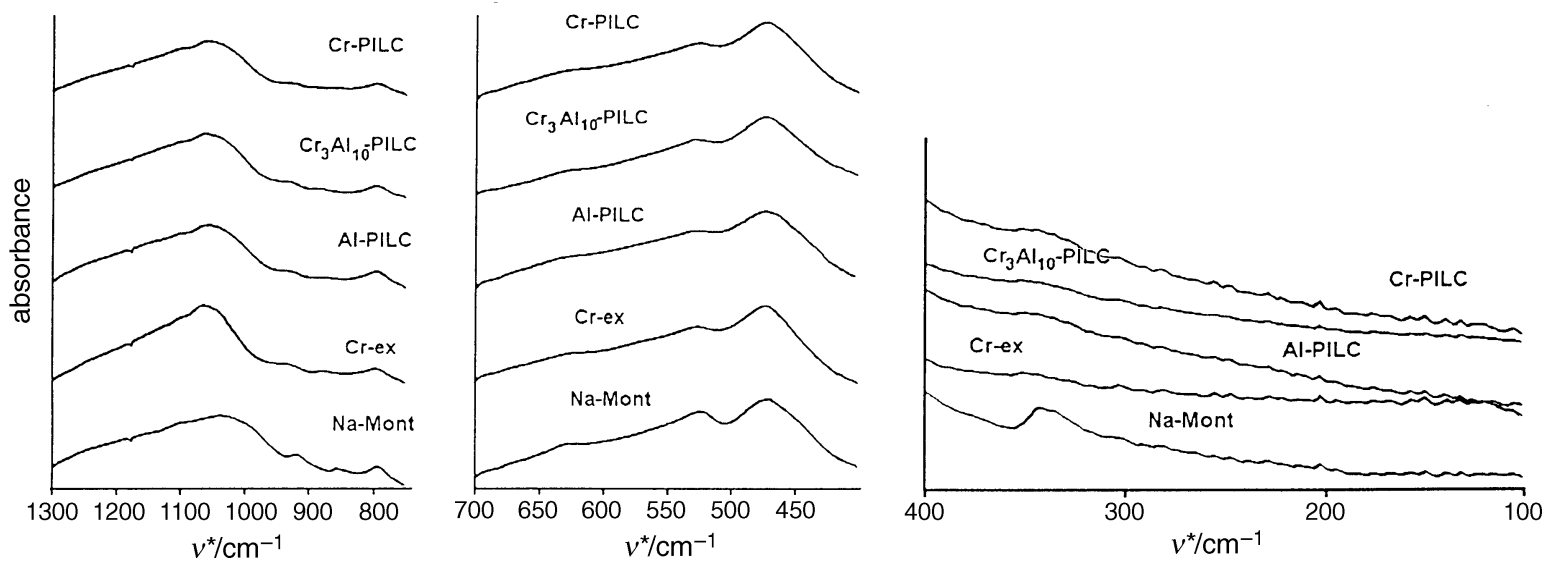

Fig. 7 IR spectra of the parent montmorillonite (Na-Mont), the Al-PILC and the chromium modified clay samples in the $1300-100 \mathrm{~cm}^{-1}$ range

materials were also nearly identical (for the iron and chromium modified clays see Fig. 6 and 7, respectively).

\section{Characterisation by chemical methods}

Acidity by pyridine adsorption. Selected spectra of pyridine

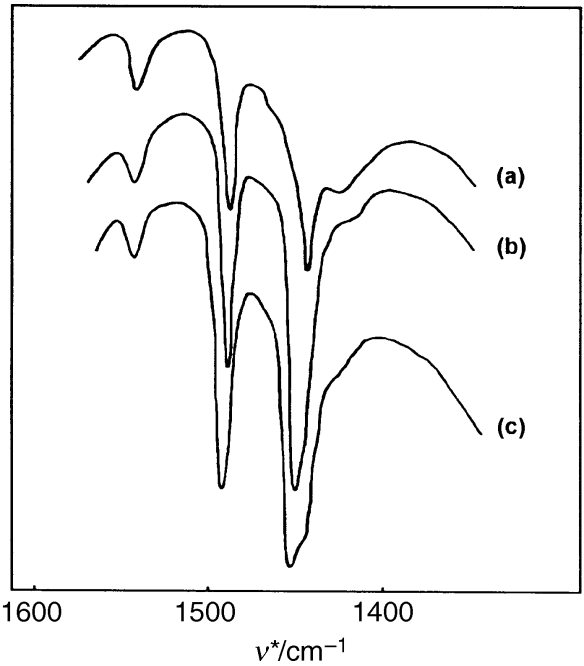

Fig. 8 IR spectra of adsorbed pyridine on (a) Fe,Na-Mont, (b) AlPILC, (c) $\mathrm{Fe}_{2} \mathrm{Al}_{11}$-PILC on various samples at $473 \mathrm{~K}$ are depicted in Fig. 8. It can be seen that both Brønsted and Lewis acid sites were present on each sample but the ratio of these acid sites was different. Similar Brønsted and Lewis acidity was found for the ionexchanged samples (e.g. $A_{\mathrm{B}} / A_{\mathrm{L}}=0.97$ for $\mathrm{Fe}_{2} \mathrm{Na}$-Mont). For the pillared samples, Lewis acidity predominated $\left(A_{\mathrm{B}} / A_{\mathrm{L}}=\right.$ 0.27 and 0.12 for $\mathrm{Al}_{13}$-PILC and $\mathrm{Fe}_{2} \mathrm{Al}_{11}$-PILC, respectively). Negligible Brønsted acidity was found for the parent $\mathrm{Na}-$ Mont.

Acidity by chemical reactions. Literature results indicate that the kinetic properties (activity and/or selectivity) of many reactions correlate with acidity. Examples are: (i) ring opening of cyclopropane and the oligomerisation of product propylene, ${ }^{26}$ (ii) double bond isomerisation of but-1-ene ${ }^{27}$ [at $373 \mathrm{~K}$ the $(Z) /(E)$-but-2-ene ratio is $c a$. 1]; (iii) dehydration of propan-2-ol; ${ }^{28}$ (iv) rearrangement of 2,3-dimethylbutane-2,3diol (pinacol) to 3,3-dimethylbutan-2-one (pinacolone) ${ }^{29}$ and (v) the isomerisation of methyloxirane yielding propanal. ${ }^{30}$ Results from these test reactions are summarised in Table 5.

Redox properties of the Cr-containing materials. The oxidation of 1-phenylpropan-1-ol to propiophenone did proceed on the co-pillared layer and the Cr-exchanged clays, but allylic oxidation did not. The specific rate of the reaction increased with chromium content (Fig. 9). 


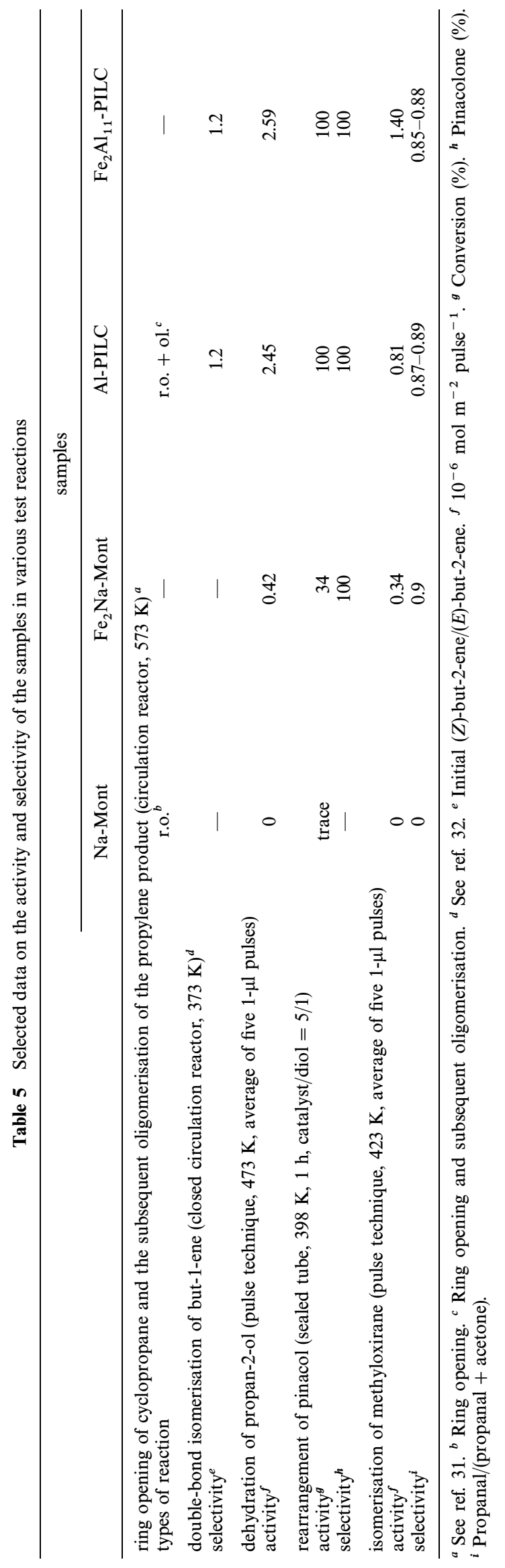



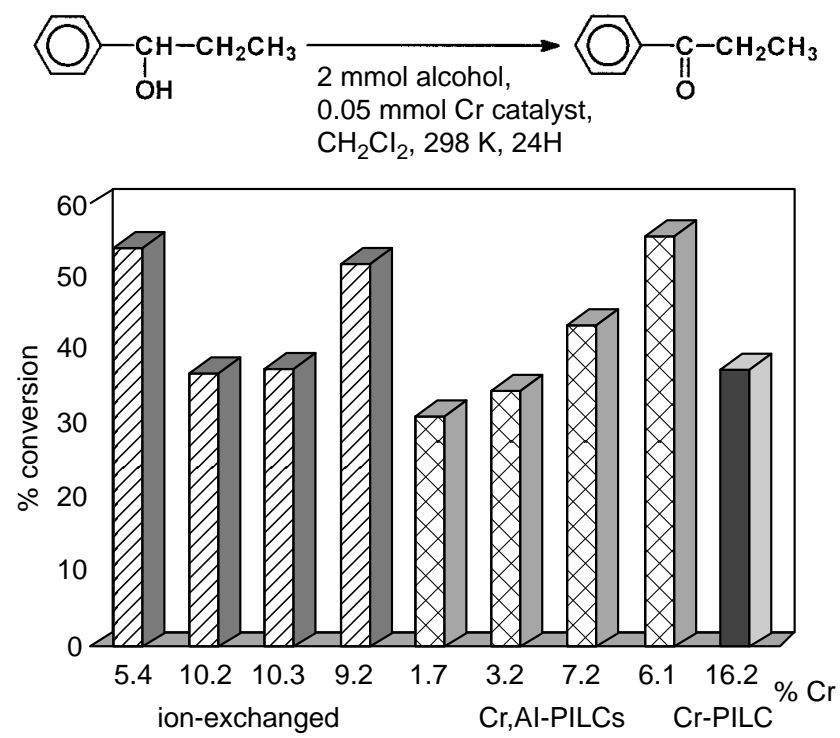

Fig. 9 Specific activity of $\mathrm{Cr}$-containing clays in the oxidation of 1phenylpropan-1-ol

\section{Discussion}

First, the problem of isomorphous substitution in the precipitated sulfate salts is discussed in some detail, based on literature-deduced considerations and on the characterisation results. Secondly, the structural properties and the catalytic behaviour of the mixed-metal pillared clays are discussed. Some overlap is however, unavoidable.

Before commencing any experiments one should be suspicious of the incorporation of either $\mathrm{Fe}^{3+}$ or $\mathrm{Cr}^{3+}$ in any of the positions, but especially the tetrahedral position, of the $\mathrm{Al}_{13}$-Keggin ion, since their large size $\left[\mathrm{Cr}^{3+}\right.$ octahedral $(0.76$ $\AA)$, ionic radius for tetrahedral coordination is not given; $\mathrm{Fe}^{3+}$ tetrahedral $(0.63 \AA$, high-spin complex), octahedral (0.69 $\AA$, low-spin complex, $0.79 \AA$, high-spin complex)] compared to $\mathrm{Al}^{3+}$ tetrahedral $(0.53 \AA)$, octahedral $(0.68 \AA)^{33}$ should introduce considerable strain into the polyhydroxy ion. While successful incorporation of $\mathrm{Fe}^{3+}$ or $\mathrm{Cr}^{3+}$ ions (among others) into zeolitic frameworks (isomorphous substitution of iron ${ }^{34}$ or chromium $^{35}$ for aluminium) is well proven, in these instances, the whole crystal can help release the strain. With iron substitution there is another problem. The use of $\mathrm{Fe}^{\mathrm{II}}$ salt in the attempted preparation of mixed-metal Keggin ions, instead of the usual $\mathrm{Fe}^{\mathrm{III}}$ salt, must be justified. It is true that the aqueous (partial) hydrolysis of $\mathrm{Fe}^{\mathrm{III}}$ ions gives iron polyhydroxy cations of various forms, which can be exchanged into cationic positions of e.g. Na-montmorillonite. Cohydrolysis with $\mathrm{AlCl}_{3}$ would provide a chance for isomorphous substitution of $\mathrm{Fe}$ for $\mathrm{Al}$, only if the rates of hydrolysis for the two salts are close. It is also known, however, that, in the presence of $\mathrm{Al}^{3+}, \mathrm{Fe}^{\mathrm{III}}$ salts undergo hydrolysis instantly forming iron hydrous oxides with highly ordered structure. ${ }^{36}$ The rate of hydrolysis can be slowed down using iron(II) salt, which is oxidized in air and in acidic solution slowly to iron(III). Then the slowly forming iron(III) may hydrolyse sufficiently slowly to give a chance for iron incorporation.

${ }^{27} \mathrm{Al}$ solution NMR measurements revealed that Keggin units did form whether $\mathrm{AlCl}_{3}$ itself or mixed-metal salts were subjected to partial hydrolysis. They could be separated as sulfate precipitates and could be studied by quantitative NMR (for a preliminary report, see ref. 37). The $\mathrm{Al}^{\mathrm{O}} / \mathrm{Al}^{\mathrm{T}}$ ratio clearly evidenced that the sulfate salt of the pure polyhydroxy aluminium really had the expected $\mathrm{Al}_{13}$-Keggin structure. Even though the solid-state NMR spectra of the cohydrolysed and coprecipitated Keggin sulfate salts are complex, resonances belonging to aluminium sitting in the octahedral or tetrahedral positions can be easily separated. The $\mathrm{Al}^{\mathrm{O}} / \mathrm{Al}^{\mathrm{T}}$ ratio either does not change ( $\mathrm{Cr}$,Al sulfate) or decreases, instead of the tremendous increase, which should occur if substitution in the tetrahedral position does takes place. Tetrahedral substitution for $\mathrm{Cr}^{3+}$ would have been surprising, since octahedral coordination is usually adopted; there are only a very few examples of tetrahedrally coordinated $\mathrm{Cr}^{3+}$ and, in such cases, $\mathrm{Cr}^{3+}$ is at the centre of a complex anion and the tetrahedron is highly distorted. ${ }^{25}$ In this salt, octahedral substitution does not occur either, since the $\mathrm{Al}^{\mathrm{O}} / \mathrm{Al}^{\mathrm{T}}$ ratio remained close to 12 , exactly as in the 'pure' $\mathrm{Al}_{13}$-Keggin ion. The results of chemical analysis indicated also that octahedral substitution for iron was highly improbable.

FTIR measurements on the salts lend further support, since the position of the $(\mathrm{Al}-\mathrm{O})^{\mathrm{T}}$ did not change in the ironmodified salt and the $(\mathrm{Cr}-\mathrm{O})^{\mathrm{T}}$ resonance could not be observed in the chromium-modified salts. At low iron concentration, resonances for octahedrally positioned iron was not observed, while those typical of octahedral aluminium remained detectable and unshifted. In the chromium-modified salts $(\mathrm{Al}-\mathrm{OH})^{\mathbf{O}}$ resonances could be registered, however, the IR spectra gave no information about incidental chromium substitution in the octahedral position.

${ }^{57} \mathrm{Fe}$ Mössbauer spectroscopy saw iron in octahedral positions but never in tetrahedral ones. The easy autoreduction upon evacuation indicates that octahedral iron was easily accessible and was not 'buried' in a complex structure such as the $\mathrm{Al}_{13}$-Keggin ion.

In our view, these results, together, allow us to state confidently that isomorphous substitution of iron or chromium for aluminium does not occur, either in the tetrahedral or the octahedral positions of the $\mathrm{Al}_{13}$-Keggin ion.

Even some measurements on the pillared layer clays gave additional evidence. TPD measurements indicate (for a preliminary report, see ref. 38) that reduction of iron ions in Na-Mont was more difficult than for those in the ionexchanged sample, where the majority of iron is in the ionexchange positions (Na-Mont: $773 \mathrm{~K}, \mathrm{Fe}, \mathrm{Na}-\mathrm{Mont}$ : $681 \mathrm{~K}$ ). This means that the iron ions in Na-Mont should be sitting in the silicate layer, substituting aluminium and/or magnesium. During ion exchange with the $\mathrm{Al}_{13}$-Keggin ion, some of the iron ions may have migrated to positions which were more easily accessible by hydrogen, and hence the maximum in the TPR curve shifted to lower temperature $(740 \mathrm{~K})$. Further decrease was observed when cohydrolysed $\mathrm{AlCl}_{3}$ and $\mathrm{FeCl}_{2}$ were used for pillaring $(703 \mathrm{~K})$. This temperature is now close to that of the maximum for the Fe,Na-Mont sample, indicating that the two structures are similar. The easy reducibility of $\mathrm{Fe}^{\mathrm{III}}$ in Fe,Al-PILC, revealed by Mössbauer spectroscopy, (see relative intensity after reduction at $473 \mathrm{~K}$ ) also shows that isomorphous substitution of $\mathrm{Fe}$ for $\mathrm{Al}$ did not occur.

In the NMR spectra of the PILCs the pillaring process can be followed, since the signal for tetrahedral aluminium clearly sharpened in the $\mathrm{Al}_{13}$-PILC compared to that of Na-Mont. However, the $\mathrm{Al}^{\mathrm{O}} / \mathrm{Al}^{\mathrm{T}}$ ratio remained quasi-constant, as the initial ratio for Na-Mont was close to that of the Al-PILC. For $\mathrm{Fe}, \mathrm{Al}$ and the $\mathrm{Cr}, \mathrm{Al}$ co-pillared montmorillonite samples, these ratios also remained similar, showing again that no isomorphous substitution took place in the pillaring process. Moreover, the influence of the paramagnetic ions on the ${ }^{27} \mathrm{Al}$ NMR spectra was negligible.

Introduction of polyvalent ions resulted in an increase in Brønsted acidity for both the ion-exchanged and the pillared montmorillonites, although Lewis acidity was predominant for the latter. Catalytic activity for the test reactions corresponded to acidities determined by pyridine adsorption. Whereas Na-Mont exhibited negligible activity in dehydration 
and isomerization reactions, the activity of iron ion-exchanged samples increased steadily with increasing degree of ionexchange. Even higher activities were observed for the pillared samples. In the double-bond isomerization of but-1-ene the $(Z) /(E)$ ratio of but-2-ene was $c a .1$ on the ion-exchanged and pillared samples, a value typical for acidic zeolites. Although ring-opening of cyclopropane also occurred on Na-Mont, the product propylene underwent oligomerisation only over the more acidic pillared layer clay. The high selectivity of propanal formation in the isomerization of methyloxirane was shown to be characteristic of highly acidic oxides. ${ }^{30}$ This was also found for the ion-exchanged and the pillared materials in this study. Moreover, the high selectivity of the pinacol rearrangement (formation of pinacolone vs. dehydration to diene) indicated that the reaction took place in the interlayer spacing of the layered silicate. The interlayer distance allows easy intercalation of pinacol, followed by selective dehydration and concomitant methyl migration under dry reaction conditions (without any solvent). Diene formation in similar systems is believed to occur on weaker surface acidic sites.

The Cr-containing clays were active in alcohol oxidation. In the mixed $\mathrm{Cr}, \mathrm{Al}$ pillared clays, upon heat treatment, the loss of outer-sphere water and dehydroxylation at higher temperatures resulted in the formation of bulky alumina pillars decorated with chromia species. These species are on the alumina pillars and become increasingly accessible to the reactant, since in the oxidation reaction the specific activity increased with chromium content. It is known, however, that the oxidizing agent is not the $\mathrm{Cr}^{\mathrm{III}}$ ion. The role of the cooxidant tert-butylhydroperoxide is to make the inactive $\mathrm{Cr}^{\mathrm{III}}$ ions active by oxidizing them and maintaining the high oxidation state throughout the reaction. Nevertheless, Cr-PILC was not the most active catalyst, since the large amount of bulk $\mathrm{Cr}^{\mathrm{III}}$ in the pillar is not available for the reactant.

\section{Conclusions}

The combination of various types of measurements on the partially hydrolysed and coprecipitated Keggin-type sulfate salts and TPD and ${ }^{57} \mathrm{Fe}$ Mössbauer measurements on the pillared materials gave definite proof that isomorphous substitution of aluminium for either iron or chromium did not occur, either in the tetrahedral or the octahedral positions of the $\mathrm{Al}_{13}$-Keggin ion. Instead, cohydrolysis and copillaring takes place, leading to $\mathrm{Al}_{13}$-pillared layer clays where the pillars are decorated with hydrous iron or chromium oxides. After heat treatment the resulting mixed-metal pillared layer materials are good and selective catalysts in many acidcatalysed transformations and also in oxidation reactions.

This work was supported by the National Science Foundation of Hungary through grants T14275, T16761 and T21131. Thanks are also due to the Belgian Prime Minister Office (PAI-projects) and the Belgian FNRS for generous financial help.

\section{References}

1 J. F. Keggin, Nature (London), 1933, 131, 908.

2 G. Johansson, Acta Chem. Scand., 1960, 14, 769, 771.

3 R. A Schoonheydt, J. Van den Eynde, H. Tubbax, H. Leeman, M. Stuyckens, I. Lenotte and W. E. E. Stone, Clays Clay Miner., 1993, 41, 598.

4 R. Szostak and C. Ingram, Stud. Surf. Sci. Catal., 1995, 94, 13.

5 D. E. W. Vaughan, US Pat., 4666 877, 1987.

6 R. Bertram, S. Schönherr and H. Görz, Z. Chem., 1987, 27, 183.

7 S. M. Bradley, R. A. Kydd and R. Yamdagni, Magn. Reson. Chem., 1990, 28, 746.

8 S. M. Bradley, R. A. Kydd, R. Yamdagni and C. A. Fyfe, Expanded Clays and Other Microporous Solids, ed. M. L. Occelli and
H. E. Robson, Van Nostrand Reinhold, New York, 1992, vol. II, ch. 2, p. 13.

9 S. M. Bradley and R. A. Kydd, J. Chem. Soc., Dalton Trans, 1993, 2407.

10 S. M. Bradley, R. A. Kydd and R. F. Howe, J. Colloid. Interface Sci., 1993, 159, 405.

11 X. Tang, W.-Q. Xu, Y.-F. Shen and S. L. Suib, Chem. Mater., 1995, 7, 102.

12 R. Bertram, S. Schönherr and H. Görz, Z. Chem., 1984, 24, 225.

13 J. Barrault, C. Zivkov, F. Bergaya, L. Gatineau, N. Hassoun, H. van Damme and D. Mari, J. Chem. Soc., Chem. Commun., 1988, 1403.

14 Y. W. Lee, B. J. Tatarchuk, Hyperfine Interact., 1988, 41, 661; Y. W. Lee, R. H. Raythatha and B. J. Tatarchuk, J. Catal., 1989, 115, 159.

15 A. Kostapapas, S.L. Suib, R. W. Cuglin and M. L. Occelli, Stud. Surf. Sci. Catal., 1989, 49, 399.

16 F. Bergaya and J. Barrault, Pillared Layered Structures: Current Trends and Applications, ed. I. V. Mitchell, Elsevier, Amsterdam, 1990, p. 167; F. Bergaya, N. Hassoun, L. Gatineau and J. Barrault, Stud. Surf. Sci. Catal., 1991 63, 329.

17 F. Bergaya, N. Hassoun, J. Barrault and L. Gatineau, Clay Miner., 1993, 28, 109.

18 D. Zhao, G. Wang, Y. Yang, X. Guo, Q. Wang and J. Ren, Clays Clay Miner., 1993, 41, 317.

19 D. Zhao, Y. Yang and X. Guo, Zeolites, 1995, 15, 58.

20 J. W. Akitt, Prog. Nucl. Magn. Reson., 1989, 21, 1.

21 J. J. Fripiat, Catal. Today, 1988, 2, 281

22 J-F. Lambert, S. Chevalier, R. Franck, H. Squet and D. Barthomeuf, J. Chem. Soc., Faraday Trans., 1994, 90, 675.

23 D. Plee, F. Borg, L. Gatineau and J. Fripiat, J. Am. Chem. Soc., 1985, 107, 2362.

24 S. M. Bradley, R. A. Kydd and R. Yamdagni, J. Chem. Soc., Dalton Trans., 1990, 2653.

25 F. A. Cotton and G. Wilkinson, Advanced Inorganic Chemistry, Wiley, Chichester, 5th edn., 1988, p. 680.

26 I. Kiricsi, I. Hannus, K. Varga and P. Fejes, J. Catal., 1980, 63, 501; H. Förster and J. Seebode, Acta Phys., 1985, 31, 413; I. Kiricsi and H. Förster, J. Chem. Soc., Faraday Trans. 1, 1988, 84, 491.

27 T. J. Weeks, Jr, I. R. Ladd, C. L. Angell and A. P. Bolton, J. Catal., 1974, 33, 256; S. Ceckiewicz, A. Baranski and J. Galuszka, J. Chem. Soc., Faraday Trans. 1, 1978, 74, 146, 2027; J. Datka, J. Chem. Soc., Faraday Trans. 1, 1980, 76, 2437; 1981, 77, 391, 1309, 2633; H. Förster and R. Seelemann, J. Chem. Soc., Faraday Trans. 1, 1981, 77, 1359; J. B. Nagy, A. Abou-Kais, M. Guelton, J. Harmel and E. G. Derouane, J. Catal., 1982, 73, 1; L. R. M. Martens, P. J. Grobet and P. A. Jacobs, Nature (London), 1985 315, 568 .

28 K. Tanabe, M. Misono, Y. Ono and H. Hattori, New Solid Acids and Bases; Their Catalytic Properties, Kodansha, Tokyo/ Elsevier, Amsterdam, 1989.

29 E. Guttierez and E. Ruiz-Hitzky, Mol. Cryst. Liq. Cryst., 1988, 161, 453.

30 Á. Molnár, I. Bucsi, M. Bartók, G. Resofszki and Gy. Gáti, J. Catal., 1991, 129, 303.

31 I. Hannus, I. Pálinkó, G. Tasi, A. Béres and I. Kiricsi, Bull. Chem. Soc. Jpn., 1996, 69, 1429.

32 A. Béres, I. Hannus and I. Kiricsi, React. Kinet. Catal. Lett., 1995, 56, 55.

33 Ref. 25 , pp. $1387-1388$.

34 S. S. Singh and H. Kodama, Clay Clay Miner., 1994, 42, 606.

35 E. M. Flanigen, J. M. Bennett, R. W. Grose, J. P. Patton, R. M. Kirchner and J. V. Smith, Nature (London), 1978, 271, 512; S. Bordiga, R. Buzzoni, F. Geobaldo, C. Lamberti, E. Giamello, A Zecchina, G. Leofanti, G. Petrini, G. Tozzola and G. Vlaic, J. Catal., 1996, 158, 486 and references therein; G. Goldfarb, K. G. Strohmaier, D. E. W. Vaughan, H. Thomann, O. G. Poluektov and J. Schmidt, J. Am. Chem. Soc., 1996, 118, 4665.

36 N. Ulagappan and C. N. R. Rao, Chem. Commun., 1996, 1047; J. D. Chen, H. E. B. Lempers and R. A. Sheldon, J. Chem. Soc., Faraday Trans., 1996, 92, 1807.

37 J. B. Nagy, J.-C. Bertrand, I. Pálinkó and I. Kiricsi, J. Chem. Soc., Chem. Commun., 1995, 2269.

38 J. Valyon, I. Pálinkó and I. Kiricsi, React. Kinet. Catal. Lett., 1996, 58, 249.

Paper 6/07209G; Received 22nd October, 1996 